\title{
"I work all the time- He just waits for the animals to come back" Social impacts of climate changes: A Greenlandic case study
}

\author{
Roanne Van Voorst \\ $\mathrm{PhD}$ candidate in Anthropology \\ Amsterdam Institute for Social Science Research (AISSR) \\ r.vanvoorst@uva.nl
}

\section{ABSTRACT}

Understanding human adaptation to climate changes is one of the most important research issues within the area of global environmental change, accounting for the fact that people worldwide are currently adapting to their changing environment (Adger and Kelly 2000: 253; Smit et al. 2008).

The Greenlandic case study as presented in this paper is mainly based on a literature analysis and ethnographic data obtained during the Greenlandic winter of 2008, with emphasis on the latter. Participant observation and interviews were combined with a discursive analysis of climate change-related policies. The empirical findings as presented in this paper suggest that an exclusive and gender-neutral focus of policy makers on economic aspects of adaptation to climate changes may increase socio-economic inequality as well as male domestic violence over women.

Social research can help to identify such chains of reactions resulting from climate changes and related policies, by focusing on individual adaptation strategies of male and female actors in vulnerable societies.

\section{KEYWORDS}

climate changes, adaptation, social inequality, gender, policy

\section{Introduction}

At this moment, tourists are not only offered seal meat, dried whale and polar coffee in Greenlandic supermarkets, but also small parts of an ice glacier. The relatively high price of this 'pure, clean ice' is defended by its slogan stamped in red warning letters on the package: 'Buy Greenlandic ice....before it has melted'.

Although potential buyers do not need to hurry - the ice cap of 2.6 million cubic kilometres covers $80 \%$ of the country and will probably not melt within the lifetime of one generation -, the advertisement does refer to a real threat. Global warming will occur twice as fast in the Arctic as in the rest of the world and Greenland's ice is melting faster than anywhere else (Walther et al., 2002:391; Gathman 2007:2). More precisely: its icecap currently still accounts for 10 percent of all the world's fresh water, but loses 60 to 90 cubic miles of ice every year - more than all of the ice in the Alps put together (ICC, 2003; Hanna et al., 2008:2). 
In Greenland, the effects of climate changes are already being experienced in daily life. Inuit, who have always known their environment so well, now face difficulties sustaining their hunting livelihoods (Rasmussen, 2005:138; Holm, 2007:3). A research among Inuit proved that they found winds have become unpredictable; the ocean is warmer and its currents more variable, while sea ice conditions are changing rapidly (Holm, 2007:4).

Not surprisingly, Greenland has become the symbol of expected future natural disasters worldwide and is called a 'living laboratory' for researchers on environment and climate change (European Commission, 2007).

The Arctic is considered one of the best places to study human adaptations to climate change for three reasons (Berkes \& Jolly, 2001:2). Firstly, as mentioned above, the effects of climate change in Greenland will be felt earlier and more severely than elsewhere in the world. Secondly, many Inuit living in settlements are highly dependent on hunting and fishing for food and their livelihoods, and therefore are indirectly dependent on the climate (ICC, 2003; Holm, 2007:2). Thirdly, the people of the Arctic have always lived with a high degree of environmental variability, making the capacity to adapt to extreme variability part of the Inuit life (Boas, 1998:72; Berkes \& Jolly, 2001:2; Sejersen, 2003:44).

Inuit social security in the context of pervasive and unpredictable change has been facilitated historically by extensive knowledge of local environments and related skills; flexible harvesting strategies; mobility and flexibility of group size; and strong social networks (Csonka \& Schweitzer, 2004:13). For example, Danish lieutenant Gustav Holm described in his travel journal in 1888, how the Inuit in East Greenland survived extremely harsh winters by following the seasonal animal movements; Inuit communities set up houses in places where animals were abundant for hunting and resettled when the animals had moved again (Holm, 1972; Baruske, 1976). Such flexible characteristics of Inuit society have enabled them throughout history to survive in the Arctic (Ford, 2005:2).

Hence, one could argue that the Inuit are used to dealing with times of duress when game was scarce or hunting conditions particularly unfavourable. Yet, current times carry an extra handicap for hunters: not only has hunting become difficult due to climate change induced environmental changes, but hunters are also more restricted to hunting certain species than they were in former times. As will be elaborated on in greater detail, Greenlandic environmental policies nowadays limit the amount and number of prey to be caught, in order to protect wildlife.

This article is an attempt to examine the impacts of such policies on social inequality amongst villagers in South Greenland. The investigation starts with an analysis of the ways in which climate changes and modernisation in Greenland are interlinked, together creating socio-economic problems for the inhabitants of hunter settlements.

The third section provides background information on the area where research was conducted and on the methodologies used during fieldwork. Then the empirical findings are presented, showing the adaptive strategies as created by male and female household members. 
Families nowadays use alternative economic strategies to deal with their current economic problems. For example, females in the village have become the main financial provider of the family. As a final adaptation strategy, some families migrate to cities, while others cannot afford to move. The sixth section then explains how above strategies have far-reaching consequences for the social hierarchies and gender roles in Inuit society.

The paper ends with a concluding chapter, in which it is argued that if gendered changes in social roles are not focused upon by policymakers in times of socio-economic change, gender inequality may become worse. The same argument may well go for economic inequality in society.

\section{Modernisation and climate changes}

In order to understand better the current situation of the inhabitants of contemporary Greenland, it needs to be underlined that climate changes alone are not responsible for all major socio-economic changes in the country. Neither are they the only reason for people migrating away from hunter settlements to larger towns. Rather, it is the combination of two main forces that has impacted Greenlandic society deeply in the past fifty years.

Firstly, modernisation is penetrating into traditional hunter lifestyles. Within fifty years, Greenland has undergone a transformation from a traditional hunter's society, into a modern commercial fishing economy (Andersen, 2008:5; Rasmussen, 2005:110). Contemporary Greenland is a mostly urban country. Only 20 percent of the Greenlanders still live in settlements, and professional hunters form an even smaller minority. However, hunting still carries a highly symbolic meaning in Greenland, and is regarded as the 'authentic Greenlandic lifestyle'. Even more, for those living in settlements, hunting activities form a crucial input into the household economy (Greenlandic Home Rule, 2007; Danish Ministry of Foreign Affairs, 2007b). This means that the household economy of villagers is highly affected by climate changes.

In recent years, this process of modernisation has been strongly accelerated by a second force in Greenlandic society: the climate changes. Although researchers rightly worry about the impact of climate changes and modernisation processes on the livelihoods of the people that live in and from the Arctic environment (Ford, 1999:146; Cochran, 2007), they may in fact be a blessing for Greenland's national economy. The country's thick icecap is believed to cover vast amounts of oil and minerals, which are currently being exposed due to the rising temperatures (Secher 2005: 6; Hansen 2008). The international community follows this process with great commercial interest and over a hundred oil licenses have been sold to investors (NOVA, 2007; Graff, 2007 Martini, 2007; Bureau of Minerals and Petroleum, 2008; Lorentzen, 2008). Also, climate changes make it easier to grow vegetables and to breed sheep in Southern regions, offering new potential jobs for future generations of urban Greenlanders.

In order to stimulate these arising opportunities and under pressure from different international actors protecting wildlife, the Greenlandic government is torn between the wish to maintain the hunting heritage and the need they feel for modernisation. The latter seems to be 
dominant. Currently, the main political goal of the government focuses on the establishment of the sustainable economic development of the country and on further financial independence from Denmark (Greenlandic Department of Employment 2007b:35; Enoksen, 2008b). An example of this economic focus is the dismantling of the 'Uniform Price System' in 2005, which formerly ensured that basic necessities such as electricity would cost the same everywhere in the country (Winther, 2008:4). Since then, however, electricity prices in South Greenlandic villages have increased strongly, which has forced poor hunter households to move out of the villages (Van Voorst, 2008:56).

Hence, the combination of modernisation and climate changes has opened up new economic possibilities for Greenland. In fact, the global forces of modernisation and climate changes have a mutual influence: modernisation itself causes environmental pollution, which is in turn said to instigate climate changes. Climate changes also bring along new limits and opportunities for national economies and - in the case of Greenland - make a faster modernisation process possible.

This strong link is not unique to Greenland. On the contrary, researchers have found that the two processes affect each other worldwide (Ribot, 1996:3; Leach et al., 1997:226; Leichenko \& O'Brien, 2001:4). Yet such potential interactions between the effects of climate change and ongoing economic changes associated with modernisation are still too often neglected in climate change related research. Traditional notions of vulnerability tend to hold global trends constant, thereby missing the key driving forces of modernisation that alter patterns of vulnerability (Leichenko \& O'Brien, 2001). Although most scholars admit that modernity should not be dismissed in research on climate change and livelihood adaptation (Adger, 1999:250; Lestrelin \& Giordano, 2006:16; Yaro, 2006:154), it is not always addressed as such.

\section{Social inequality and domestic violence}

As the prime minister of Greenland said during the Arctic Ocean Conference in May 2008: "As a result of climate change, new opportunities will arise, and we want to take part in securing that these developments will benefit all" (Enoksen, 2008a). If as much oil and as many minerals are found in the Greenlandic soil as is expected, then the first part of his prediction is probably true. It is likely that oil will provide money and employment in Greenland.

The second part of the prime minister's statement, however, might be difficult to accomplish. It is highly unlikely that economic developments will benefit all in Greenlandic society. As happens in many cases where governments decide to 'develop' an area (Brown, 2005:89; Arce \& Long, 2000:4), the impact at a local community-level is enormous in Greenland (Andersen, 2008:170).

People's vulnerability to climate change is dependent on the economic alternatives that they have. Worldwide, research has shown that in the interest of 'development', poverty amongst the poorest members of society may increase (Kates, 2000:13; Robbins, 2004). Taking into account the fact that economic inequality in Greenland is enormous, as with countries like Brazil and Mexico (Andersen, 2008:173), economic development could cause severe economic problems for those Greenlandic households that already live in poverty (Andersen, 2008:173). 
Indeed, climate changes create economic opportunities for the inhabitants of South Greenland. However, for most poor households in small hunter-villages, these economic alternatives are out of reach. In order to become a mine worker in South Greenland, one needs official education. In order to become a shepherd, one needs money to invest in sheep. Most poor families do not possess enough of either resource. As a result, economic problems in these Greenlandic hunter households are increasing (Rasmussen, 2005:13; Van Voorst, 2008). These findings correspond with those of Frank Ellis (1998:33) and of other researchers who argue that some natural resource management strategies disadvantage local and poor populations worldwide, increasing their vulnerability and dependency on natural resources, rather than decreasing it (Thomas \& Twyman, 2005:117; Ford et al., 2006:147).

In Greenlandic society, two groups can be singled out as the most vulnerable to these current processes. First of all, poor hunter families living in settlements are strongly disadvantaged by the combination of climate changes and hunting restrictions. Hunting has become more difficult than in past times as a direct consequence of the melting ice. For example, drifting ice floes from the melting ice cap block sea routes more and more often. In practice, this means that hunters are not able to sail out on such days because their small motorboats cannot sail through the ice-lumps. On top of this nuisance, people are not allowed to hunt as much as they were in past times. The Greenlandic government has increased the number of environmental policies in order to limit hunting and protect animals in times of climate change (Greenland Home Rule, 2001; Hansen, 2002:6; Sejersen, 2003:115; Siegstad, 2008).

In a more indirect way, there is a second group that is disadvantaged by the combination of climate changes and environmental policies: the female members of Greenlandic hunter families in villages. The problems as experienced with hunting by males have a negative impact on the self-esteem of male hunters, and this indirectly affects their spouses' physical well being. In other words: climate changes and modernisation processes seem to stimulate male dominance over women.

Violence against women has been identified as a significant problem in the Arctic. According to Wagner Sorensen, violent Greenlandic men use violence against their spouse as a rational act in order to enforce the rules at home. In Wagner Sørensen's words, these men 'think that they are entitled to set the scene, set certain standards and rules and make sure they are kept' (Wagner Sørensen, 2001:82). The increase in violence of the past decades has been attributed mainly to a male loss of identity and self-worth in a fast changing society in which males lose their hunter-roles. Hence, even though most women in Greenland nowadays should be considered the breadwinner, their male partners still try to hold on to their former role of 'head of the household' (Williamson et al., 2004:201; Csonka \& Schweitzer, 2004:60; Greenland Home Rule, 2008).

\section{The case study}

Villagers in South Greenland live in a mixed economy (wage income and subsistence harvesting) and obtain much of their protein from hunting and fishing activities. Due to a lack of fish, 
the local cod-factory was closed down two years ago, putting more than half of the working population out of work. The majority of the 40 households in the research setting Nunaqarfik ${ }^{1}$ now combine frequent hunting with 'community jobs' - which in practice means inhabitants shovel snow or fetch water for the school and the elderly in return for the minimum wage, paid by the Greenlandic government, with the help of Danish subsidies (Municipality of Qaqortoq, 2008; Andersen, 2008:11).

Most men try to sustain a hunting livelihood, even though that has become difficult due to climate changes and environmental policies. As soon as the weather is good enough, they sail out to hunt and provide for their family. If a hunt has been very successful and the weather allows for a longer trip, males sail to town where they sell the meat at the market.

The daily life of women in the hunter-settlement appears quite different. While in older days, Greenlandic women mostly helped their husbands by the flensing of caught prey and the cleansing of animal skins; these tasks have now been largely taken over by factory employees in larger towns. In the past fifty years, more and more Greenlandic women have taken up modern jobs. In Nunaqarfik, most females have found community jobs or other 'modern' jobs in their village such as teaching in the local school, helping the elderly or cleaning the church. Since most women have not had any formal education, their wages are generally very low. Hence, for the majority of families, hunting activities remain a crucial input into their household economy. Not only is a Greenlandic meal (a catch, mostly consisting of seal, whale, seabird or fish) cheaper than a European meal (food purchased in a shop), it is also highly valued as 'traditional Greenlandic'; healthy, nutritious and tasty.

There was more activity in the village in past times - many villagers dreamily spoke of the soccer team that once existed and of the 200 inhabitants that lived amongst them - but many of the coloured, wooden houses were quite recently abandoned. Mainly it was those villagers who are too poor to migrate to the nearby town (and as a result are too dependent of the communal strategy of food sharing as will be explained in the next section) that stayed behind in the settlement. At the time of conducting the fieldwork, only 79 people were still present in the village. In search of new jobs or education, most other inhabitants had moved away to Qaqortoq, which is the closest town. With 3000 inhabitants, Qaqortoq is the largest town in South Greenland and is regarded as the Greenlandic centre of knowledge. There is an upper secondary school, several commercial colleges and a farming school where students learn to become shepherds.

From the village, it takes one hour to sail to Qaqortoq, and a helicopter flies back and forth once a week. However, just as daily activities in Greenland are determined by the weather, travel opportunities to and from the settlement are also highly dependent on weather conditions. For example, in the winter of 2008 it was impossible for over a month either to sail or fly, since drifting ice blocks, extreme cold and strong Northern winds made all trips life threatening.

During the three month-fieldwork period, qualitative interviews were held with all villagers living in Nunaqarfik. Other research methods used during fieldwork were: participant 
observation with males and females in their daily activities, quantitative analysis of relevant policies, analysis of local newspaper articles and interviews with politicians. In the interviews with Greenlandic males and females living in the settlement, the focus was on the division of financial incomes within households, the status attached to different livelihood-strategies, the influence on decision making within the household and the eventual use of physical domestic violence. Moreover, all families that had moved away recently from the village to a town nearby were interviewed as well, in order to analyse the longer-term effects of their national migration.

\section{Male adaptive strategies}

As was explained above, the alternative economic opportunities offered by the government, for example in mining and farming, are out of reach of most locals in Greenlandic hunter settlements. In order to cope with the economic struggles created by climate changes, males and females in Nunaqarfik have therefore created alternative adaptation strategies.

When analysing the impacts of climate changes and environmental policies upon a society, a gendered approach is necessary due to the fact that women often have different views on environmental problems than men (Robbins, 2004:59; Kurian, 2000:6), and because they perceive environmental risk in a different manner (Gustafson, 1998:807; Davidson \& Freudenberg, 1996:336). Furthermore, gender influences economic opportunities and differentiating access to natural and economic resources (Wenzel, 2000:63; Koenig, 2005:80; Cohen, 2005:13; Chant, 2006:105).

Analysis of the data gathered in Nunaqarfik showed that Inuit males adapt to climate changes and processes of modernisation, by making use of modern equipment in order to sail out despite climate change related problems. Wealthier males invest in more expensive motorboats that are better able to sail through drifting ice, while less wealthy males take along inexpensive materials such as a rope that might come in useful when their boat gets stuck between ice floes. Also, males take different routes and try to increase their catch whenever possible. Rather than shooting as many animals as needed for the family, hunters now shoot as many animals as they can, in order to save them for times of food shortage. Regarding the fact that hunting of specific species is officially restricted, this means that hunters sometimes hunt illegally.

On many if not most days, however, sailing was impossible due to the unpredictable storms and drifting ice floes. Looking out over the sea in the early mornings, hunters often pointed out dark clouds in the sky to each other with worried faces. "Sila ajorpoq,' the weather is bad," the men eventually concluded, before they walked back home to spend the rest of the day cleaning their rifles and listening to weather reports on the radio. As an old hunter explained: "before, hunting was easier than it is now. Every night before I went to bed, I looked outside the window to predict the weather for the next day. Mostly it was okay, sometimes it was bad, and sometimes it was good. The weather and I - we understood each other. Now, it has switched. It behaves strangely, I cannot predict it anymore."

Whenever the weather was good enough and males were able to sail, villagers participated in a shared adaptive strategy of food sharing. On successful hunting-days, the inhabitants of 
Nunaqarfik walked up and down between their own house and the homes of others. The plastic bag in their hands contained freshly caught prey, and was carried with care. The carriers knocked on doors, opened them while shouting a greeting and placed the bag in families' hallways. The receiving family than shouted back 'Qujanaq' (thank you), and sometimes invited the sharing person to come inside for a mug of coffee and a gossip.

Through this communal adaptive strategy of food sharing, the catches of seals, fish and birds were shared amongst all villagers, and everyone was able to survive despite the problems they face with the weather conditions. According to village members, hunter males have strongly increased the amount of sharing amongst village members in recent, difficult, years. The elderly, or those not able to catch enough food to feed their household members, are supported by more successful hunter males.

In return for food, receiving families show their respect to the sharing hunters, and in some cases, they accept dominant behaviour by the sharing hunter. The more successful a hunter, the more connected he is believed to be with nature and therefore the higher his status is in the village. In difficult times with few available animals, such as during the winter of 2008, any hunting success is highly appreciated. Whenever a hunter returned home with prey, he was met with a cheerful atmosphere by other villagers at the harbour. After the hunter had disappeared with his prey in the direction of his house, people often praised his skills by pointing out the intelligence and traditional knowledge one needs in order to hunt successfully. The fact that one local hunter had caught a polar bear, an animal highly valued in Greenland, was a story recapitulated by many families as soon as this hunter's name was mentioned, and some even had photos of the event. In accordance with other research on the Inuit, competence and survival skills in the nature were thus highly valued in this village (Freeman, 2005:25; Dahl, 2000:13).

Interestingly enough, many scholars assume that modern times brought along a decrease in traditional food sharing rituals in Inuit society (see for example Hansen, 2002). Clearly, this seemed not to be the case in Nunaqarfik. Rather, the opposite seemed to occur.

Following Marcel Mauss' ideas on gift cycles within communities, the returning of gifts - in this situation, shared prey - is obligatory (Mauss, 1990:33). Describing the many different forms of dividing property in Inuit society, Tim Ingold also explains that the sharing of meat amongst village-members should not be regarded as a free gift. Rather, recipients are expected to return the favour at some appropriate time in the future (Ingold et al., 1988:102).

In Nunaqarfik, only a few people were able to return food to hunters. In fact, most were only able to 'give' the hunters status and prestige in return for the favour. If hunting becomes even more difficult in the future due to further climate changes, it is likely that this kind of return will no longer be sufficient. Hunters might not be willing to - or able to - continue sharing their food with others if their own economic problems increase. It seems, therefore, unlikely that the communal adaptive strategy of food sharing will be economically sustainable in the long run. 
Although the system of food sharing has functioned relatively well now, this adaptation strategy is, in the words of James C. Scott, a "cul-de-sac" (Scott 1976: 205).

\section{Female adaptive strategies}

Greenlandic females are less directly affected by the climate changes than males, because they often already have modern jobs and do not work within nature, as their hunting husbands do. In order to deal with the economic problems caused by climate changes, they try to control household finances and make as much money as possible by working extra hours and saving on expenditure.

In practice, this means that most hunter males have become financially dependent on their wife's income. For example, the income of the wife is used to invest in better hunting materials. According to a young hunter's wife, she would not want it to be different since her share in the hunting provides her with an identity: "You know, without him, I am just me and I work in a shop, yes? But with him, I am a hunter's wife. That is who I am, and I cannot be something else. And without me, he could not be a hunter because he cannot pay for the boat. So I give him the money."

For this reason, women pay the rent, electricity and heating bills, as well as for clothing and most supermarket groceries. They also often calculate how much is left to spend and provide their husbands with money needed for new equipment on the boat. This, however, does not mean that women also make the decisions about what their income is spent on.

Frank Ellis suggests that engagement in independent income sources may raise the social status of women within the household. His research in sub-Saharan Africa showed that the negotiating position of women across a range of household decisions improved after they had started to make their own money (Ellis, 1998:34). In the hunter settlement in Greenland, no comparable results were found. Only those women in better financial positions, who were able to migrate out of the village, improved their bargaining position, as the next section will describe in greater detail. Despite the fact that their husbands had become financially dependent on them, women in Nunaqarfik were generally not able to gain power in the household. As an example, the following case study of a female victim of domestic violence in the settlement is useful:

The lively conversation of a group of women stops abruptly as soon as Arnannguaq ${ }^{I I}$, a mother of two sons and a cleaner in the school, walks by in the village. Although she looked down in order to avoid their gazes, it was clear that she had been in a fight the night before. Her face was strangely coloured blue and red and she walked with a limp. Shy but determined she approached the women. "He hit me again", she said. "He drank and I said we have no money for alcohol. Then he got angry. I don't know what to do". Now it was the women's turn to look down. Finally, one responded: "My advice is to go back to him. What else can you do? You need him, to eat" (Extract from field notes, February 2008).

In fact, it was not only the victim herself who needed her husband to provide her with food: four out of the five women in the above group were also frequently provided with his prey. 
In order for the women to help the victim, they would have had to bear a degrading relationship with a man who was of great economic importance to their families. Since most other villagers argued along the same lines, and no police, social worker or psychologist was available in the village, escaping from male dominant behaviour was extremely difficult for Greenlandic females- even though they had become financial providers for the household.

Other than the above explanations, the differences between the findings of Ellis, who claims that women will gain power when they become financially engaged, and those of the data obtained during fieldwork in Greenland might be explained by two further reasons. First of all, I agree with Sylvia Chant that when analysing the balance of power between males and females, intra-household power relations and resource distributions should be considered just as important as female financial independence (Chant, 2006:87). Greenlandic women in the settlement earned their own money, yet they were not able to control their incomes due to the high value attached to their husband's occupation.

Secondly, I believe that female respondents in the South Greenlandic case-study were not empowered due to what James C. Scott refers to as the communal social guarantees in the village: those who are most dependent on others economically are forced to accept local norms and values, in order to receive economic help (Scott, 1976:43). Women have become financially independent, yet they accept the dominant behaviour of their husbands and sometimes even physical abuse because males share prey with other village members. In the village, more value is attached to the male income of prey, than to the financial support of women. Although males have become financially dependent on their wives, the status of these males increases because a close network of other villagers is economically dependent on the hunters. Because of this high economic dependency, community members accept the dominant behaviour of males over females.

\section{Climate migration and challenged gender patterns}

A final adaptive strategy used by wealthier families in Nunaqarfik is migration to the town closest by. Within two years, over 13 families, the equivalent of 41 people, had moved from the village to the town, in search of better jobs. All of these families mentioned the climate changes as a main reason for migration.

In the town, all migrated females appeared to be much more successful economically than males. This might be explained by the fact that the economic alternatives available to them suited their work-experience much better than did the economic alternatives for men. As a result, males often became unemployed, and eventually depressed because their status decreased and because they had difficulties adapting to urban life. As one male hunter explained, three months after he had moved to town: "Back in the village everybody liked me because I am a good hunter. But here, my skills and myself, we are worth nothing. I can do a lot of useful things, but I do not have a diploma and therefore people say I am no good. For example, if I predict the weather here, people are not interested."

James C. Scott's theory on the communal social guarantees helps to explain another reason for the improved situation of women: in town, hardly any value is attached to male hunting 
occupations. This might be explained by the fact that while males in the village shared their prey with other families; such extensive social sharing networks do not exist in the town. Hence, whereas in the village, male prey was valued over female income, in towns this situation is reversed. Here, the modern occupations of Greenlandic females are considered important, because money is valued as a more practical and therefore better form of income. This means that after migration to town, females were no longer dependent on their husband's prey for status and food, and were no longer forced to accept traditional norms concerning male dominance. The new economic division within households allowed women to renegotiate and challenge the power balance between males and females. This finding corresponds with the conclusions of Joke Schrijvers, analysing the changing gender patterns in a refugee camp after recent migration (Schrijvers, 1999:327).

In Greenland, the differing experiences of males and females of the urban life created tension within all households that had moved from the village to town in the past two years. In the majority of households in the sample, domestic violence of males over females had increased. In most cases, men drank excessive amounts of alcohol in an attempt to suppress their feelings of depression, and seemed to release their hidden frustrations on their successful and thriving wives. As one of the males explained: "everything here was different than I expected it to be. I cannot hunt; I cannot find a job... There happens a lot inside my body, inside my head. Pain, you understand? So yes, sometimes I want a little bit of fun and I drink, and then I get angry. Because my wife has become so selfish here! And so, yes, maybe I hit her sometimes, yes."

Different studies worldwide showed that in socio-economic changes where males lose selfconfidence, an increase of male dominance over females is to be expected (Williamson et al., 2004:201; World Bank, 2000; Silberschmidt, 2001:676). For example, Taylor Momsen argues that social rules in society often put men at an advantage when an socio-economic change occurs, since sudden, economic change (...) creates new gender differences in which women are generally the losers' (Momsen, 2004:7). She argues that women worldwide carry a double burden of work as they cope with housework, children and subsistence food (Momsen, 2004:2).

However, recent research criticizes the above findings in two manners. Firstly, Bo Wagner Sorensen warns not to consider males as 'victims' of social changes. According to Wagner Sorensen, violent Greenlandic males do not use violence as a reaction to external pressures (changing gender roles, for example), but rather as a 'habit', or to set up the rules at home. Domestic violence should thus be seen as an offspring from dominant characters, rather than as a 'new' situation created by social changes (Wagner Sørensen, 2001:89; Wagner Sørensen, 1998:158). Indeed, only blaming the outer world for the violent behaviour of Greenlandic males, could wrongly suggest that males themselves carry hardly any responsibility for beating up their spouses. However, the data presented in this paper clearly indicate that there is a strong correlation between changing gender roles and an increase of domestic violence. I would therefore argue that although social circumstances alone did not create the abuse, male dominant behaviour was strongly influenced by them. Feelings of depression and a loss of self- worth were increasingly experienced by males, which then worsened the 'habit' of physical abuse against females. 
Secondly, other findings suggest that societal changes do not necessarily have a negative impact on women. Even though some say that globalisation has engendered poverty (Sassen, 2000:504), others explain that for some young women, globalisation has created new jobs (Momsen, 2004:239) and an increase of power. For example, women's employment in Kenya has shifted the gender balance of power between married males and females. As a result, women in society no longer consider domestic violence to be 'normal', but rather believe it to be 'unfair'. Although the majority of males do not yet share this view, it could mean that more Kenyan women in the future will try to protect themselves against domestic violence (Silberschmidt, 2001:658). In a similar fashion, men and women of vulnerable livelihood systems in Ghana are negotiating different activity roles and access patterns to household capital due to climate changes (Yaro, 2006:149). Women worldwide have reported they gained power within the household after they had become financially independent of their husbands (World Bank, 2000). In a fishers' village in Canada, women felt they were empowered after the fish populations declined. According to them, the new jobs they picked up in order to sustain a livelihood provided them with more self-assurance, while their husbands 'have chosen to stay sitting in the bar, literally and figuratively crying in their beer' (Davis, 1993:469).

In the case of Greenland, the expectation of increased male dominance proved only partly true. Greenlandic males who migrate from settlement to town are generally economically unsuccessful and their status has decreased dramatically in comparison with how it stood in the village. In that respect, they seem to be more vulnerable to climate changes and linked economic changes than women. As an indirect result, domestic violence of men towards females increased after migration - at first.

However, some individual females have ultimately been empowered due to their financial success in towns. In the long run, some females seem able to gain power within the household or improve their personal situation by leaving their husbands. More than half of the families that had moved from the village to Qaqortoq over the past two years are now divorced, or said to have serious relationship problems. One young woman, for example, feels that maintaining her relationship with her husband in the town is an impossible mission: "He had hit me before, also in Nunaqarfik. I did not know how to stop him, you know? Then we went here and it got worse. He has no job, no money, and he hit me every time he drank. I told him; I pay this house. If you hit me again, you must go. He never changed. I left him now". The woman found help through a social worker, and now lives with her children at her sister's apartment.

This example not only shows that the urban situation offers women more opportunities to escape domestic violence due to the availability of official help-institutions, but it also shows that urban females are more self-confident than they seemed to be in the village. According to many, they have come to realise "what we are worth in town. And that is a lot. People need us here, we are good workers; we make good money". Or, in the words of an older woman who moved away from the settlement half a year ago, and left her husband only a month later: "We don't need those drunken aggressors anymore. We can take care of ourselves now."

The above findings suggest that research on gendered patterns in society should be conducted not only directly after - or during - socio-economic changes in a community, but also after a 
longer period of time. In the Greenlandic case, analyses of recently migrated families would have resulted in a view of females as the victims of climate changes and environmental policies because the physical abuse of women by their husbands often increased after migration. Yet, a later fieldwork study might suggest that some females are eventually empowered - while males seem unable to improve their personal situation.

\section{Conclusion}

This South Greenlandic case study provides an example of the ways in which a chain of reactions results from the changing natural and economic opportunities created by climate changes. Based on research conducted in 2008 , this paper has argued that modernization processes and climate changes are intrinsically linked. Together, the forces alter the context in which families sustain a livelihood. Since political decisions in Greenland are focused on modernisation, shaping national economic changes and environmental policies, it is argued in this paper that their social effects on people's livelihoods should be examined with a focus on socio-economic inequality and gender.

As the case study in South Greenland shows, the concept of dynamic vulnerability and adaptation is relevant in climate change related research. Exploring 'the extent to which environmental and economic changes influence the capacity of (...) social groups to respond to various types of natural and socio-economic shocks.' (Leichenko \& O'Brien, 2001:3) helped to show that in Greenland, it is not just climate changes that make people economically vulnerable, but rather, the combination of climate changes and environmental policies that limits people's adaptation options. With the help of a more dynamic approach to vulnerability, it can be analysed how people's adaptation options are affected by climate changes, in a constantly changing economic and political environment.

While climate changes and linked environmental policies benefit some groups and regional purposes, in Greenland, they have harmed most members of a local and poor community in an economic and social way. The ability of families in South Greenland to adapt to their new natural and socio-economic environment reflects existing differences between social class and power (Kates, 2000; Blaikie et al., 1994). This became clear from an analysis of the adaptation techniques used by Greenlandic males: Inuit males from wealthier families are able to hunt during difficult circumstances caused by climate change by using, amongst other things, modern techniques and devices. In other words: modernisation has increased the adaptation options of those who can afford the adjustment, thereby decreasing their vulnerability to climate changes. At the same time, poor households are increasingly unable to pay the costs of adaptation, because they lack the means to switch jobs or to make the necessary financial investments.

In the village where the fieldwork took place, families were impacted in two main ways. Firstly, most households faced economic problems due to the combination of climate changes and environmental policies. The current environmental policies in Greenland forbid Greenlandic males to hunt for specific animals or at specific times and no realistic economic alternatives are offered, forcing them to compensate by hunting in dangerous weather-conditions, to suffer from hunger, or to join the food sharing cycle. I therefore propose that a minimum base line be inserted into environmental policies, assuring a minimal income for households. Secondly, 
gender patterns in communities have been challenged. Although villagers did not have to pay in cash to receive prey in a communal sharing system, the food sharing was not free of charge. In return for their generosity, hunters gained high status, as well as power within the household.

Moreover, the combination of the climate changes and linked environmental policies in Greenland affects traditional gender patterns in society, which indirectly increases male dominance over women. However, in wealthier households that migrate to the town, male members seem to be more vulnerable to climate changes and environmental policies, because they have more difficulties than women in adapting to the socio-economic changes, and they therefore lose status. It is argued that climate changes and environmental policies ultimately stimulate the dominant behaviour of males over females in settlements in Greenland.

In this case study, gender-neutral policies reinforce gender divisions in communities (Ribot, 2008: personal communication). Therefore, in male dominated communities where it can be expected that male self-esteem decreases due to socio-economic changes, policy makers could try to protect women from an increase of male dominance, for example by providing information in the village about women's rights, or by providing help to those women who want to leave their aggressive husbands, as well as to men who face depression due to a loss of selfworth. For instance, professional psychological help could be offered to males and females in the hunter-village.

As Dora Davis concluded after fieldwork in a Canadian fishing community, national environmental policies have enormous impacts on power divisions between males and females: "The current changes [in gender patterns] can be directly traced (...) to dramatic changes in the local economy, which in turn reflect changes in the much wider spectrum of the global capitalism or the political economy" (Davis, 1993:471). Since policies connected to climate changes affect human beings worldwide, and sometimes even threaten their human security - as happens in Greenland - it is important for policy makers to keep in mind the eventual side effects of environmental policies for local people. It was stated in the introduction of this paper that a better understanding of gendered impacts of adaptive strategies used within households could help to improve national policies intended to stimulate economic growth in an equal way.

Absolute equality in communities cannot be considered a realistic goal within environmental policy. Like every socio-economic change, climate changes and linked environmental policies will benefit some and disadvantage others. However, if policies ignore inequality between the genders and social class in a community, differences are likely to become worse.

\section{References}

ADGER, W. N. 1999. Social vulnerability to climate change and extremes in coastal Vietnam. World Development, 27(1):249-269, February.

ADGER, W.N. and KELLY, P.M. 2000. Theory and Practice in Assessing Vulnerability to Climate 
Change and Facilitating Adaptation. Climatic Change, 47(4):325 -352, December.

ANDERSEN, M.K. 2008. Gronland. Maegtig og Afmaegtig. Copenhagen: Gyldendal. 319 p.

ARCE, A. and LONG, N. 2000. Reconfiguring Modernity and Development from an Anthropological Perspective. (In Arce, A. \& Long, N., eds. Anthropology, Development and Modernities. Exploring Discourses, Counter-tendencies and Violence. London: Routledge, p 1-32.)

BARUSKE, H. 1976. Eskimo Sprookjes. Utrecht: A.W. Bruna \& Zoon. 183 p.

BERKES, F. and JOLLY, D. 2001. Adapting to Climate Change: Social-Ecological Resilience in a Canadian Western Arctic Community. Conservation Ecology 5(2). http://www.consecol.org/vol5/iss2/ art18/ Date of access: 13 February, 2008.

BLAIKIE, P., WISNER, B. and CANNON, T. 1994. At Risk: Natural Hazards, People's Vulnerabilities, and Disasters. London: Routledge. 267 p.

BOAS, F. 1998. Franz Boas among the Inuit of Baffin Island, 1883 - 1884. Journals and Letters. Toronto: University of Toronto Press. 298 p.

BROWN, T. 2005. Contestation, Confusion and Corruption: Market-based Land Reform in Zambia. (In Evers, S., Spierenburg, M. \& Wels,H., eds. Competing Jurisdictions. Settling Land Claims in Africa. Leiden: Koninklijke Brill NV. p. 79-102.)

BUREAU OF MINERALS AND PETROLEUM. 2008. Mining and Oil. Nuuk: Bureau of Oil and Petroleum. http://www.greenland.com/content/english/business_and_investment/setting_up_business_in_greenland/mining_oil Date of access: 2 February, 2008.

CHANT, S. 2006. Contributions of a Gender Perspective to the Analysis of Poverty. (In Jaquette, J.S., $\&$ Summerfield, G., eds. Women and gender equity in development theory and practice. Institutions, Resources and Mobilization. Durham: Duke University Press. p. 87-106.)

COCHRAN, P.A.L. 2007. The secretary-general's high level event on climatic change. General Assembley, New York. Available: United Nations. Date of access: 30 March 2007.

COHEN, J.H. 2005. Why some people stay while Others Leave. (In Trager, L., ed. Migration and Economy. Global and Local Dynamics. Oxford: Altamira Press. p. 103-126.)

CSONKA, Y. and SCHWEITZER, P. 2004. Societies and Cultures: Change and Persistance. Arctic Development Report. http://www.svs.is/AHDR/AHDR\%20chapters/English\%20version/Chapters\%20 PDF.htm Date of access: 22 December, 2007.

DAHL, J. 2000. Saqqaq: an Inuit hunting community in the modern world. Toronto: University of Toronto Press. 257 p.

DANISH MINISTRY OF FOREIGN AFFAIRS see DENMARK. MINISTRY OF FOREIGN AFFAIRS.

DAVIDSON, D. and FREUDENBERG, W. 1996. Gender and environmental risk concerns: A review and analysis of available research. Environment and Behavior, 28:302-339.

DAVIS, D.L. 1993. When men become "women": Gender antagonism and the changing sexual geography of work in Newfoundland. Sex Roles, 29(8):457-489, March.

DENMARK. MINISTRY OF FOREIGN AFFAIRS. 2007. Greenland. http://www.denmark.dk/en/ menu/AboutDenmark/GreenlandTheFaroeIslands/Greenland. Date of access: 12 December 2007.

ELLIS, F. 1998. Household strategies and rural livelihood diversification. Journal of Development Studies, 35(1):1-38, April. 
ENOKSEN, H. 2008a. Speech at opening the Arctic Conference in Illulisat. http://uk.nanoq.gl/ Emner/News/News_from_Parliament/2008/05/ /media/2D155968C13F48E1B9A55E153E593A3F. ashx. Date of access: 25 May 2008.

ENOKSEN, H. 2008b. Landets økonomi under selvstyre. Grønlandsposten, 21:18 March.

EUROPEAN COMMISSION. 2007. Press release: President Barosso and Danish Prime Minister Anders Fogh Rasmussen visit Greenland to see climate change at first hand. Available: European Commission. Date of access: 7 November 2007.

FORD, N. 1999. Communicating climate change from the perspective of local people. A case study from Arctic Canada. Journal of Development Communication, 5(2):93-108, December.

FORD, J. 2005. The human implications of climate change for indigenous communities in the Arctic: What we can learn from past and present responses. http://atlas-conferences.com/c/a/p/x/25.htm Date of access: 10 October 2007.

FREEMAN, M.M.R. 2005. "Just one more time before I die": Securing the relationship between Inuit and Whales in the Arctic Regions. Senri Ethnological studies, 67:22-34, Winter.

GATHMAN, F. 2007. Merkel inspects a changing Climate in Greenland. Der Spiegel, 48, 23 October. http://www.spiegel.de/international/germany/0,1518,500486,00.html. Date of access: 25 November 2007.

GRAFF, J. 2007. Fight for the top of the world. Time, 170(13):24-26, 19 Sept.

GREENLAND. DEPARTMENT OF EMPLOYMENT. 2007. Strategi og Handlingsplan for energiområdet 2008-2015, No. 29.15.01.02. Nuuk: Erhvervsdirektoratet, Home Rule.

GREENLAND. HOME RULE. 2001. Tulugac kampagnen 2002-2004. [Online]. Nuuk: Greenlandic Home Rule. http://dk.nanoq.gl/emner/landsstyre/departementer/landsstyreformandens\%20department/informationskontoret_tusagassiivik/tulugaq.aspx. Date of access: 8 January 2008.

GREENLAND. HOME RULE. 2007. Greenland Statistics. Nuuk: Home Rule. 345 p.

GREENLAND. HOME RULE. 2008. Health Report. Nuuk: Home Rule. 257 p.

GREENLANDIC DEPARTMENT OF EMPLOYMENT se GREENLAND. DEPARTMENT OF EMPLOYMENT.

GREENLANDIC HOME RULE. see GREENLAND. HOME RULE.

GUSTAFSON, P.E. 1998. Gender differences in risk perception: Theoretical and methodological perspectives. Risk Analysis, 18 (6):805-811, May.

HANNA, E., HUYBRECHTS, P., STEFFEN, K., CAPPELEN, J., HUFF, R., SHUMAN, C., TRISTAM, I., WISE, S. and GRIFFITHS, M. 2008. Increased runoff from melt from the Greenland Ice Sheet: a response to global warming. http://www.sheffield.ac.uk/content/1/c6/06/78/14/hanna etal_jcli1964_in_press.pdf Date of access: 19 April 2008.

HANSEN, K. 2002. A farewell to Greenlands wildlife. Denmark: Gads Forlag. 154 p.

HANSEN, N. 2008. Masser af is mellem Grønland og Canada. http://www.dmi.dk/dmi/den_globale_opvarmning_har_ramt_groenland. Date of access: 4 February 2008.

HOLM, G. 1972. Konebaadsekspeditionen.Etnologiske skitse af angmagsalikerne 1888. Copenhagen: Rhodos Publications. 211 p.

HOLM, L. 2007. Global Warming and Climate Change, the Greenland experience. International 
Circumpolar Council: Greenland. 171 p.

ICC. 2003. Executive Council Resolution number 2003-01. http://www.inuit.org/index. asp?lang=eng\&num=244ICC 2003. Date of access: 24 November 2007.

INGOLD, T., RICHES, D. and WOODBURN, J. 1988. Hunters and gatherers, Volume II: Property, Power and Ideology. Oxford: Berg. 312 p.

KATES, R. W. 2000. Cautionary tales: adaptation and the Global Poor. Climatic Change, 45(1):5-17, April.

KOENIG, D. 2005. Multilocality and social stratification in Kita, Mali. (In Trager, L., ed. Migration and Economy. Global and Local Dynamics. Oxford: Altamira Press. p. 77-102.)

KURIAN, P.A. 2000. Engendering the environment? Gender in the World Bank's Environmental Policies. Aldershot: Ashgate. 269 p.

LEACH, M., MEARNS, R. and SCOONES, I. 1997. Environmental entitlements: A framework for understanding the institutional dynamics of environmental change. Discussion paper 359. Brighton: University of Sussex.

LEICHENKO, R. and O'BRIEN, K.L. 2001. Vulnerability Article 4: The Dynamics of Vulnerability to Global Change. http://www.ihdp.unibonn.de/html/publications/update/update01_02/ IHDPUpdate01_02_obrien.html Date of access: 27 April 2008.

LESTRELIN, G. and GIORDANO, M. 2006. Upland Development Policy, Livelihood Change and Land Degradation: Interactions from a Laotian Village. Land Degradation Development, 18(1):55-76, August.

LORENTZEN, C. S. 2008. 2007 blev rekordår for mineral-efterforskning. Greenland. Grønlandsposten, 11: January 10.

MARTINI, J. 2007. Guldgravere og diamantjaegere strommer til Gronland. Ingeniøren. http://ing.dk/ artikel/76359. Date of access: 25 March 2008.

MAUSS, M. 1990. The gift: The form and reason for exchange in Archaic societies. London: Routledge. $224 \mathrm{p}$.

MOMSEN, J.M. 2004. Gender and development. London: Routledge. 272 p.

MUNICIPALITY OF QAQORTOQ (GREENLAND). 2008. Visioner for Qaqortoq- en by i Sydgrønland. Qaqortoq: Qaqortoq Kommune. 72 p.

NOVA. 2007. [TV program] NPS, 27 December 200722.10.

RASMUSSEN, R.O. 2005. Analyse af fangererhvervet I Grønland. Denmark: Roskilde University. 134 p.

RIBOT, J.C. 1996. Climate variability, climate change and social vulnerability: Moving forward by looking back. (In Ribot, J.C., Magalhaes, A.R. and Panagides, S., eds. Climate variability, climate change and social vulnerability in the semi-arid tropics. Cambridge: Cambridge University Press. p. 1-10.)

ROBBINS, P. 2004. Political Ecology. Critical Introductions to Geography. United Kingdom: Blackwell Publishing Ltd. 264 p.

SASSEN, S. 2000. Women's burden: Counter-Geographies of Globalization and the Feminization of Survival. Journal of International Affairs, 53(2):503-524, Spring.

SCHRIJVERS, J. 1999. Fighters, Victims and Survivors: Constructions of Ethnicity, Gender and 
Refugeeness. Journal of Refugee Studies, 12(3):307-333, Autumn.

SCOTT, J.C. 1976. The Moral Economy of the Peasant. Rebellion and Subsistence in Southeast Asia. London: Yale University Press. 254 p.

SECHER, K. 2005. Mineralske råstoffer I Grønland. GeoViden, 1:14-29, Spring.

SEJERSEN, F. 2003. Grønlands Naturforvaltning, ressourcer og fangstrettigheder. Copenhagen: Akademisk Forlag A/G. 314 p.

SIEGSTAD, L. 2008. Siumut lever ikke op til sine formåls paragraffer. Grønlandsposten, 7, 7 February.

SILBERSCHMIDT, M. 2001. Disempowerment of Men in Rural and Urban East Africa: Implications for Male Identity and Sexual Behavior. World Development, 29(4):657-761, April.

SMIT, B., HOVELSRUD, G. and WANDEL, J. 2008. CAVIAR: Community Adaptation and Vulnarability in Arctic Regions. Occasional Paper (28). Guelph: University Press.

THOMAS, D.S.G. and TWYMAN, C. 2005. Equity and justice in climate change adaptation amongst natural-resource-dependent societies. Global Environmental Change, 15(2):115-124, July.

VAN VOORST, R.S. 2008. "I work all the time- He just waits for the animals to come back". Livelihood adaptation strategies of Inuit males and females to climate changes in Greenland. (Dissertation- MSc) Amsterdam: VU University. 123 p.

WAGNER SØRENSEN, B. 1998. Explanations for wife beating in Greenland. (In Klein, R.C.A., ed. Multidisciplinary perspectives on family violence. p. 153-175.)

WAGNER SØRENSEN, B. 2001. Men in Transition. The Representation of Men's Violence Against Women in Greenland. Violence Against Women, 7(7):826-847, Winter.

WALTHER, G., POST, E. and CONVEY, P. 2002. Ecological responses to recent climate change. Nature, 416(1):389-395, March.

WENZEL, G. 2000. Sharing, Money, and Modern Inuit Subsistence: Obligation and Reciprocity at Clyde River, Nunavut. (In Wenzel, G.W., ed. The Social Economy of Sharing: Resource Allocation and Modern Hunter-Gatherers. Osaka: National Museum of Ethnology. p. 61-85.)

WILLIAMSON, K.J., HOOGENSEN, G., LOTHERINGTON, A.T., HAMILTON, L.H., SAVAGE, S.,KOUKARENKO, N., KALINIANA, M., LIMSTRAND, I., STEMLAND, M., IRBACHER FOX, S., KAFAROWSKI, J., SLOAN, L. and POPPEL, M. 2004. Gender Issues. Arctic Development Report. http://www.svs.is/AHDR/AHDR\%20chapters/English\%20version/Chapters\%20PDF.htm Date of access: 22 December 2007.

WINTHER, G. 2008. The reform on Uniform Prices and its Consequences for Households in Greenland. Denmark: Aalborg University Press. 9 p.

WORLD BANK, 2000. Gender Relations in Troubled Transition. (In Crying out for Changes. Voices of the Poor. p 109-132. Available: World Bank. Date of access: 15 November 2007.)

YARO, J.A. 2006. Is deagrarianisation real? A study of livelihood activities in rural northern Ghana. The Journal of Modern African Studies, 44(1):125-156, March.

\footnotetext{
Notes

I. In order to protect the identity of informants, a pseudonym is used for the name of the settlement where the research was conducted. In Greenlandic, 'Nunaqarfik' means 'village'.

II. In order to protect informants, a pseudonym was used for this informant.
} 